\title{
К ВОПРОСУ О КУЛЬТИВИРОВАНИИ ДЕКОРАТИВНО-ЦВЕТОЧНЫХ РАСТЕНИЙ В УСЛОВИЯХ АЭРОТЕХНОГЕННОГО ВОЗДЕЙСТВИЯ МЕДНО-НИКЕЛЕВЫХ ПРОИЗВОДСТВ НА КРАЙНЕМ СЕВЕРЕ
}

\author{
Иванова Л.А., Кременецкая И.П. ${ }^{2}$, Слуковская М.В., ${ }^{2}$ Мосенз И.А. ${ }^{2}$ \\ ${ }^{1}$ Полярно-альпийский ботанический сад-институт им. Н.А. Аврорина КНЦ РАН, Апатиты, \\ ivanova_la@inbox.ru \\ ${ }^{2}$ Институт химии и технологии редких элементов и минерального сырья им. И.В. Танана- \\ ева КНЦРАH, Anamumbl, remen@chemy.kolasc.net
}

Развитие современной металлургической промышленности, характерной особенностью которой является высокий уровень эмиссии в атмосферу кислотообразующих веществ, в сочетании с природными лимитирующими факторами на Кольском Севере создает экстремальные условия для выживания растений $[1,2]$, препятствует проведению работ по ландшафтному проектированию и формированию экологически благополучной урбанизированной среды, требует поиска инновационных решений.

В 2011-2015 гг. сотрудниками КНЦ РАН была разработана, прошла комплексные опытнопромышленные испытания и предложена производству инновационная технология ускоренной реабилитации техногенных пустошей с помощью экранирующего слоя из различных мелиорантов - отходов горнопромышленного комплекса [3]. Эффективность таких работ во многом зависит и правильного подбора растений-ремедиантов.

Цель работы - разработать зональный ассортимент декоративно-цветочных растений для озеленения в условиях аэротехногенного воздействия медно-никелевых производств на Крайнем Севере.

Исследования проводились в период с 2016 по 2017 гг. на экспериментальном участке техногенной пустоши, расположенном в 0.7 км от границы промышленной зоны площадки Мончегорск $\mathrm{AO}$ «Кольская ГМК» $\left(67^{\circ} 55.783^{\prime} \mathrm{N}, 32^{\circ} 51.535^{\prime} \mathrm{E}\right)$. Он имел ровную поверхность с органогенным горизонтом, который длительное время подвергался хроническому воздействию аэровыбросов, содержащих сернистый ангидрид и тяжелые металлы, кислых грунтовых вод и смывов с территории. Как показали исследования, использование здесь традиционных методов озеленения невозможно из-за неблагоприятных почвенных условий: актуальная кислотность грунта составляет $\mathrm{pH} 4.0$, гидролитическая кислотность - 90 мг-экв/100 г; он характеризуется высокими значениями $\mathrm{Ni}, \mathrm{Zn}, \mathrm{Fe}$, экстремально высокими - $\mathrm{Cu}$ и $\mathrm{S}$ и низкими - остальных питательных элементов [4].

Объектами исследования явились 23 вида многолетних травянистых растений, из которых все, за исключением 3-х (мшанка мшанковая (Sagina saginoides (L.) Karst.), смолка альпийская (Viscaria alpina Bemh.), осока черно-бурая (Carex atrofusca Schkuhr), представлены суккулентными растениями (джовибарба побегоносная (Jovibarba sobolifera (J. Sims) Opiz), молодило паутинистое (Sempervivum arachnoideum L.), м. кавказское (Sempervivum caucasicum Rupr. ex Boiss.), м. Питтона (Sempervivum pittonii Schott., Nym. et Kotshy), м. кровельное (Sempervivum tectorum L.), м. кровельное металлика (Sempervivum tectorum L. cv. Metallicum Giganteum), м. закавказское, (Sempervivum transcaucasicum Muirhead), очиток видный (Hylotelephium spectabile (Boreau) H. Ohba), o. едкий (Sedum acre L.), о. живучий (Sedum aizoon L.), клементсия Семенова (Clementsia semenovii (Regel et Herd.) Boriss.) и к. розовоцветковая (Clementsia rhodantha (A. Gay) Rose=Rhodiola rhodantha (A.Gray) H.Jacobsen), родиола розовая (Rhodiola rosea L.), р. цельнолистная (Rhodiola integrifolia Raf.), камнеломка маньчжурская (Saxifraga manchuriensis (Engl.) Kom), к. Арендса (Saxifraga $\times$ arendsii hort. - желтая), к. Арендса (Saxifraga × arendsii hort. - красная), к. теневая (Saxifraga umbrosa L.), к. лопатчатая (Saxifraga spathularis Brot.), примула маленькая (Primula minima L.).

В качестве мелиорантов для формирования экранирующего от техногенного грунта слоя были использованы сунгулитовые отходы [8]. Они были нанесены непосредственно на техногенный торфоподобный грунт слоем высотой 10 см. 


\section{Методы исследований}

Посадку растений проводили методом рассады с использованием одиночных и групп (куртин) растений с сохранением корневого кома в 10 см слой мелиоранта из сунгулитовых отходов. Полевые исследования включали фенологические наблюдения за ростом и развитием растений (1 раз в месяц) [5]. Основными показателями, по которым оценивалась устойчивость декоративных растений к стрессовым факторам и пригодности для озеленения, были: декоративность, фаза развития и коэффициент размножения каждого вида, который определяли делением общего количества сформировавшихся за сезон деток или дочерних растений на число материнских растений тестового вида. Названия сосудистых растений даны в соответствии со сводкой С. К. Черепанова [6], суккулентных - Г. Якобсена [7]. Подкормку растений минеральными удобрениями осуществляли 1 раз за вегетационный период (сразу после схода снега) в количестве 35 г/м². Уход за посадками заключался в прополке сорняков и уборке мусора.

\section{Результаты исследований}

Подбор растений для проведения эксперимента осуществлялся согласно их биологическим и видовым характеристикам. Предпочтение отдавалось многолетним вечнозеленым растениямсуккулентам семейства Толстянковые (Crassulaceae J.St.-Hil.), отличающимся особенным строением и типом метаболизма (толстянковый или МОКТ-тип), имеющим высокие декоративные качества, низкие требования к факторам роста и развития, способным интенсивно размножаться на песчаных грунтах, каковыми являются промышленные отходы [9].

Наблюдения показали, что все высаженные растения быстро (в течение первых 2-х недель после посадки) прижились и на протяжении последующих трех месяцев (июль, август, сентябрь) интенсивно росли и развивались (табл. 1), о чем свидетельствовал их внешний вид и фаза развития растений. Все виды, за исключением родиолы розовой, молодила кавказского и Питтона, клементсии и осоки, в течение первого вегетационного периода дали многочисленное потомство. Коэффициент размножения у этих видов варьировал от 19 до 67. Шесть видов (очитки видный, едкий и живучий, клементсия, а также смолка и мшанка) процвели. При этом все высаженные особи смолки альпийской успели завязать полноценные семена. К концу вегетационного периода выпада растений не наблюдалось.

Практически все растения хорошо пережили зиму. В 2017 г. только несколько из них, из-за низких (не выше $+5^{\circ} \mathrm{C}$ ) июньских средних температур в регионе и избыточного весеннего увлажнения экспериментальной площадки, пострадали. Так, полностью погибло молодило металлика, частично повредились м. закавказское, м. кровельное, м. паутинистое. Однако при дальнейшем наблюдении отмечено, что практически все они постепенно восстановились и продолжили интенсивно расти и развиваться. Коэффициент размножения у большинства из этих видов не превышал 17. В то время как у более успешных культур - очитка едкого он равнялся 212, камнеломки красной 167 , к. маленькой - 232. В течение 2017 г. отмечен очень сильный рост таких травянистых видов как осока маленькая и мшанка мшанковая, последняя распространилась на $1 / 4$ площади экспериментальной делянки и была частично удалена. Семена смолки, высыпавшись на поверхность отходов, проросли и образовали плотные куртины; их площадь, по сравнению с 2016 г., увеличилась, как минимум, в 2 раза. Из 22 выживших видов 14 обильно цвели (все очитки, большинство видов камнеломок и радиол, клементсия Семенова и к. розовоцветковая, а также смолка и мшанка), остальные растения находились в стадии вегетации, осока черно-бурая - кущения.

В процессе наблюдений за опытными растениями было отмечено гармоничное сочетание высоких декоративных качеств растений с интенсивным ростом, развитием и размножением, низкими требованиями к факторам роста, легкостью в уходе и быстро создаваемым декоративным эффектом, а также выявлен ряд достоинств, главные из которых: сохранение декоративности с ранней весны до поздней осени, продолжительное цветение. В течение одного сезона они успевают сформироваться во взрослое растение и образовать многочисленные дочерние растения, не требуют мощного слоя питательного грунта. Химическое воздействие аэротехногенных выбросов на надземную 
часть растений таких растений минимально (поллютанты не проникают в растение, т.к. с осадками мигрируют с поверхности органов вниз в грунт). Не требуется дополнительный полив растений в засушливый период.

Таблица 1. Результаты наблюдений за ростом и развитием растений в эксперименте 2016-2017 гг.

\begin{tabular}{|c|c|c|c|}
\hline & Вй & & иент размножения, фаза развития \\
\hline & & 2016 г. & 2017 г. \\
\hline 1 & молодило закавказское & 8. B & 11. B \\
\hline 2 & молодило кавказское & 1. B & 8. B \\
\hline 3 & молодило паутинистое & 19. B & 17. B \\
\hline 4 & молодило Питтона & 2. B & 1. B \\
\hline 5 & молодило кровельное & 13. B & 3. $\mathrm{B}$ \\
\hline 6 & молодило металлика & 3. B & погибло \\
\hline 7 & джовибарба побегоносная & 19. B & 11. B \\
\hline 8 & очиток видный & 4. Ц & 7. Ц \\
\hline 9 & очиток едкий & 67. Ц & 212. Ц \\
\hline 10 & очиток живучий & 6. Ц & 15. Ц \\
\hline 11 & клементсия Семенова & 1. Ц & 2. Ц \\
\hline 12 & клементсия розовоцветковая & 6. B & 3. Ц \\
\hline 13 & радиола розовая & 1. B & 2. Ц \\
\hline 14 & радиола цельнолистная & 7. $\mathrm{B}$ & 5. B \\
\hline 15 & камнеломка Арендса - желтая & 54. B & 112. Ц \\
\hline 16 & камнеломка теневая & 3. B & 4.B \\
\hline 17 & камнеломка Арендса - красная & 37. $\mathrm{B}$ & 167. Ц \\
\hline 18 & камнеломка маньчжурская & 8. B & 12. Ц \\
\hline 19 & камнеломка лопатчатая & 3. B & 8. Ц \\
\hline 20 & примула маленькая & 21. B & 232. Ц \\
\hline 21 & мшанка мшанковая & 15. Ц & Ц. интенсивное самораспространение \\
\hline 22 & смолка альпийская & 3. Ц. П & 13. Ц. П \\
\hline 23 & осока черно-бурая & 2. B & 6. K \\
\hline
\end{tabular}

Примечание: В - вегетация, Ц - цветение, П - плодоношение, К - кущение.

Декоративные качества и биологические особенности этих видов позволяют успешно применять их на Крайнем Севере в условиях продолжающегося аэротехногенного воздействия при создании различных цветочных композиций.

\section{Выводы}

Разработан зональный озеленительный ассортимент декоративно-цветочных растений, включающий 22, преимущественно суккулентных вида, способных интенсивно расти и развиваться на местных минеральных промышленных отходах в зоне с повышенным уровнем промышленного загрязнения.

Среди главных достоинств растений, предлагаемых для ландшафтного озеленения, выделены: высокая декоративность, интенсивный рост и развитие, легкость в уходе, пластичность, высокая жизненность и быстро создаваемый декоративный эффект. 


\section{Литература}

1. Душкова Д. О., Евсеев А. В. Анализ техногенного воздействия на геосистемы Европейского Севера России // Арктика и Север. Архангельск: ФГАОУ ВПО «Северный (Арктический) федеральный университет». № 4. 2011. С. 162-196.

2. Зюзин Ю. Л. Суровый лик Хибин. Мурманск: Рекламная полиграфия, 2006. 236 с.

3. Иванова Л.А., Слуковская М.В., Марковская Е.Ф., Кременецкая И.П. Использование горнопромышленных отходов для реабилитации техногенно трансформированных почв Субарктики // Экологическая геология: теория, практика и региональные проблемы: Материалы четвертой научно-практической конференции. Петрозаводск. 30 сентября-2 октября 2015 г. Воронеж: Изд-во: Научная книга. 2015. С. 217-219.

4. Слуковская М.В., Иванова Л.А., Горбачева Т. Т., Дрогобужская С.В., Иноземцева Е.С., Марковская Е.Ф. Изменение свойств техногенно загрязненного грунта при использовании карбанатитового мелиоранта в зоне воздействия медно-никелевого комбината // Тр. Карельского научного центра РАН. №6. 2013. C.133-141.

5. Фенологические наблюдения (организация, проведение, обработка). Л.: Наука. 1982. 224 с.

6. Черепанов К.С. Сосудистые растения России и сопредельных государств (в пределах бывшего СССР). СПб.: Мир и семья. 1995. $992 \mathrm{c.}$

7. Jacobsen H. Das Sukkulentenlexikon. VEB Gustav Fischer Verlag. 1970. 589 s.

8. Slukovskaya M.V., Ivanova L.A., Kremenetskaya I.P., Gorbacheva T.T., Drogobuzhskaya S.V., Lashchuk V.V., Markovskaya E.F. Rehabilitation of Industrial Barren in Arctic Region Using Mining Wastes. The Open Ecology Journal, 2018, 11:1-13. DOI: 10.2174/1874213001811010001 ISSN: 1874-2130.

9. Zanis M., Zimmer E.A., Chen Z.D., Savolainen V., Chase M.W. The earliest angiosperms: evidence from mitochondrial, plastid and nuclear genomes // Nature. 1999. V. 402. P. 404-407. 